\title{
PENGARUH MOTIVASI INTRINSIK, KEPUASAN KERJA DAN BUDAYA ORGANISASI TERHADAP KINERJA PEGAWAI BIRO KEPEGAWAIAN DI BADAN KEPEGA WAIAN NEGARA (BKN) JAKARTA
}

\author{
Indra Suryadi \\ Sugito Efendi \\ Email: indrasuryadi95@gmail.com, efendisugito@yahoo.co.id \\ Program Studi Manajemen Fakultas Ekonomi \\ Universitas Nasional
}

\begin{abstract}
ABSTRAK
Penelitian ini bertujuan untuk menguji dan menganalisis pengaruh motivasi instrinsik, kepuasan kerja dan budaya organisasi terhadap kinerja pegawai Biro Kepegawaian di Badan Kepegawaian Negara (BKN) Jakarta. Populasi penelitian ini adalah 172 pegawai Biro Kepegawaian di BKN Jakarta. Dengan rumus Slovin, sampel penelitian ini terdiri dari 120 pegawai Biro Kepegawaian di BKN Jakarta. Metode analisisnya adalah regresi linear berganda. Hasil penelitian menunjukkan bahwa motivasi instrinsik, kepuasan kerja dan budaya organisasi secara parsial berpengaruh positif dan signifikan terhadap kinerja pegawai Biro Kepegawaian di BKN Jakarta.
\end{abstract}

Kata kunci: Motivasi intrinsik, kepuasan kerja, budaya organisasi, kinerja pegawai

\section{ABSTRACT}

This research aims to test and analyze the effect of intrinsic motivation, job satisfaction and organizational culture on employee performance of Staffing Department in National Civil Service Agency (BKN) Jakarta. Population in this research is 172 employees of Staffing Department in BKN Jakarta. By Slovin formula, samples in this research consisted of 120 employees of Staffing Department in BKN Jakarta. The analysis method was multiple linear regression. Results of the research showed that intrinsic motivation, job satisfaction and organizational culture partially has positive and significant effect on employee performance of Staffing Department in BKN Jakarta.

Keywords: Intrinsic motivation, job satisfaction, organizational culture, employee performance

\section{PENDAHULUAN}

Sumber daya manusia mempunyai peran utama dalam setiap kegiatan perusahaan. Sumber daya manusia yang berkualitas akan mampu mencapai kinerja yang dikehendaki perusahaan. Semakin banyak jumlah karyawan yang mampu mencapai kinerja yang dikehendaki perusahaan, maka semakin baik kinerja perusahaan tersebut. Kinerja perusahaan yang baik akan membantu perusahaan tersebut untuk mencapai visi dan tujuannya. Oleh karena itu, meski didukung sarana dan prasarana serta sumber daya yang memadai, perusahaan tetap tidak mampu mencapai hasil yang optimal tanpa adanya sumber daya manusia yang berkualitas dan berkinerja tinggi. 
Badan Kepegawaian Negara (BKN) merupakan Lembaga Pemerintah Non Kementerian yang bertugas melaksanakan tugas pemerintahan di bidang manajemen kepegawaian negara. Salah satu fungsi BKN adalah menyusun dan menetapkan kebijakan teknis di bidang manajemen kepegawaian serta menyelenggarakan dan mengembangkan sistem rekrutmen Pegawai Negeri Sipil (BKN, 2017). Kinerja BKN Jakarta dalam melaksanakan fungsi rekrutmen dan manajemen terhadap Pegawai Negeri Sipil (PNS) di Jakarta secara tidak langsung dapat mempengaruhi kinerja para PNS lain di Jakarta yang bekerja di lembaga pemerintahan lain di luar BKN. Oleh karena pentingnya peran BKN Jakarta tersebut, BKN Jakarta diharapkan dapat senantiasa mencapai kinerja yang optimal dalam rangka mewujudkan dan mengembangkan PNS yang profesional, bertanggung jawab, jujur, disiplin dan adil agar dapat melaksanakan tugasnya secara berdaya guna.

Biro Kepegawaian BKN Jakarta merupakan biro yang bertugas untuk melaksanakan fungsi manajemen terhadap pegawai yang bekerja di BKN Jakarta. Kinerja yang dicapai oleh biro ini dapat mempengaruhi kinerja yang dicapai oleh setiap karyawan BKN Jakarta. Oleh karena itu, Biro Kepegawaian BKN Jakarta dituntut untuk senantiasa menunjukkan kinerja yang baik dan efektif dalam melaksanakan tugas dan fungsinya.

Berdasarkan data yang diperoleh dari Biro Kepegawaian BKN Jakarta, terdapat beberapa indikator kinerja pelayanan Biro Kepegawaian BKN yang persentase realisasi targetnya mengalami penurunan di tahun 2016. Meskipun terdapat juga beberapa indikator lainnya yang mengalami peningkatan persentase realisasi target di periode tersebut, Biro Kepegawaian BKN perlu memperhatikan fenomena penurunan realisasi sebagian targetnya untuk mencegah terjadinya penurunan realisasi target kembali di masa yang akan datang. Biro Kepegawaian BKN perlu senantiasa berupaya untuk meningkatkan kinerjanya dan kinerja pegawainya agar dapat mencapai visi dan tujuan yang telah ditetapkan oleh instansi dan pemerintah. Dalam rangka meningkatkan kinerja pegawainya, Biro Kepegawaian BKN dapat menggunakan alat berupa berbagai variabel yang terbukti dapat mempengaruhi kinerja pegawai secara signifikan.

Salah satu variabel yang dapat mempengaruhi kinerja pegawai adalah motivasi intrinsik. Dalam penelitiannya, Prahiawan dan Simbolon (2014) serta Waruwu (2017) membuktikan bahwa motivasi intrinsik berpengaruh positif dan signifikan terhadap kinerja karyawan. Menurut Nopitasari dan Krisnandi (2018), semakin kuat motivasi intrinsik di dalam diri karyawan, maka semakin kuat keinginan karyawan tersebut untuk melaksanakan pekerjaannya dengan baik, sehingga semakin terdorong perilaku karyawan tersebut untuk diarahkan sesuai dengan standar kinerja dan tujuan perusahaan. 
Kepuasan kerja juga dapat mempengaruhi kinerja pegawai. Hasil penelitian oleh Rosita dan Yuniati (2016) serta Saputra, dkk. (2016) menunjukkan bahwa kepuasan kerja berpengaruh positif dan signifikan terhadap kinerja karyawan. Menurut Indrawan dan Dewi (2014), karyawan yang memiliki kepuasan kerja yang tinggi cenderung akan setia kepada instansi tempatnya bekerja serta termotivasi dan merasa senang dalam bekerja, sehingga dapat membantu perusahaan untuk mencapai tujuannya. Sebaliknya, karyawan yang tidak puas cenderung akan menghindari tugas dan tanggung jawabnya, sehingga dapat mengganggu proses pencapaian tujuan perusahaan.

Selain motivasi intrinsik dan kepuasan kerja, budaya organisasi juga dapat mempengaruhi kinerja pegawai. Hasil penelitian oleh Armiaty dan Ariffin (2014) serta Warni (2014) menunjukkan bahwa budaya organisasi berpengaruh positif dan signifikan terhadap kinerja karyawan. Hal tersebut menunjukkan bahwa semakin baik budaya organisasi yang diterapkan dalam suatu perusahaan, maka semakin baik pula kinerja dari karyawan yang bekerja di perusahaan tersebut.

Berdasarkan latar belakang di atas, perlu dilakukan penelitian untuk menguji dan menganalisis pengaruh motivasi intrinsik, kepuasan kerja dan budaya organisasi terhadap kinerja pegawai Biro Kepegawaian di Badan Kepegawaian Negara (BKN) Jakarta.

\section{TINJAUAN PUSTAKA}

\section{Pengertian Motivasi Intrinsik}

Hasibuan (2006) mendefinisikan motivasi sebagai pemberian daya penggerak yang menciptakan kegairahan kerja seseorang, agar mereka mau bekerja sama, efektif dan terintegrasi dengan segala upayanya untuk mencapai kepuasan. Menurut Bangun (2012:312), motivasi adalah kondisi yang mendorong orang untuk menjalankan tugas sesuai fungsinya di organisasi.

Motivasi dibedakan menjadi dua jenis, yaitu motivasi intrinsik dan ekstrinsik. Motivasi intrinsik dapat didefinisikan sebagai motif-motif yang aktivasinya tidak perlu dirangsang dari luar, karena sudah ada dorongannya di dalam diri individu (Sardiman, 2007). Menurut Gunarsa (2008), motivasi intrinsik adalah dorongan atau kehendak yang kuat dari dalam diri seseorang.

\section{Faktor-Faktor yang Mempengaruhi Motivasi Intrinsik}

Menurut Taufik (2007) dalam Danarjati, dkk. (2013), faktor-faktor yang mempengaruhi motivasi intrinsik antara lain sebagai berikut. 


\section{Kebutuhan (need)}

Seseorang beraktivitas untuk memenuhi kebutuhannya, baik kebutuhan biologis maupun psikologis.

2. Harapan (Expectancy)

Seseorang cenderung termotivasi oleh keberhasilan dan harapan untuk mencapai keberhasilan yang dapat menimbulkan kepuasan dan peningkatan harga diri serta pergerakan ke arah pencapaian tujuan.

3. Minat

Minat merupakan rasa suka dan ingin melakukan suatu hal tanpa diperintah.

\section{Indikator Motivasi Intrinsik}

Menurut Robbins (2006), motivasi intrinsik memiliki indikator berikut.

a. Prestasi, yaitu pemberian kesempatan bagi karyawan yang potensial.

b. Penghargaan, yaitu meliputi pemberian penghargaan bagi karyawan atas hasil kerja untuk mengembangkan diri.

c. Tanggung jawab, yaitu tugas karyawan agar memahami dengan benar peran dan wewenangnya.

d. Pengembangan diri, yaitu pemberian kesempatan bagi karyawan untuk maju dan berkembang dalam pekerjaan.

\section{Pengertian Kepuasan Kerja}

Menurut Hasibuan (2006), kepuasan kerja adalah perasaan menyenangi dan mencintai pekerjaan yang direfleksikan oleh moral, disiplin dan prestasi kerja. Handoko (2012:193) mendefinisikan kepuasan kerja sebagai keadaan emosional karyawan yang menyenangkan dan/atau tidak menyenangkan dalam memandang pekerjaannya. Menurut Wibowo (2010:501), kepuasan kerja adalah sikap terhadap pekerjaan yang menunjukan selisih antara penghargaan yang diterima pekerja dan yang ia yakini seharusnya ia terima.

\section{Faktor-faktor yang Mempengaruhi Kepuasan Kerja}

Menurut Hariandja (2005:291), faktor-faktor yang mempengaruhi kepuasan kerja antara lain sebagai berikut.

1. Gaji, yakni tingkat kesesuaian dan keadilan dari jumlah bayaran yang diterima seseorang atas pekerjaannya.

2. Pekerjaan itu sendiri, yakni tingkat kepuasan terhadap pekerjaan yang dilakukan. 
3. Rekan sekerja, yaitu teman interaksi dalam bekerja.

4. Atasan, yaitu orang yang memberi perintah/petunjuk terkait pelaksanaan kerja.

5. Promosi, yaitu kemungkinan seseorang untuk berkembang melalui kenaikan jabatan.

6. Lingkungan kerja, yaitu lingkungan fisik dan psikologis.

Menurut Rivai dan Sagala (2009:859), faktor-faktor yang mempengaruhi kepuasan kerja pegawai dapat dikategorikan ke dalam kelompok berikut.

1. Faktor instrinsik, yaitu faktor dalam diri pegawai yang dibawa olehnya sejak mulai bekerja.

2. Faktor ekstrinsik, yaitu faktor dari luar diri pegawai, seperti kondisi fisik lingkungan kerja, interaksinya dengan karyawan lain, dan sistem penggajian.

\section{Indikator Kepuasan Kerja}

Berdasarkan definisi yang dikemukakan Hasibuan (2006), kepuasan kerja memiliki indikator berikut ini.

1. Menyenangi pekerjaan

2. Mencintai pekerjaan

3. Moral kerja

4. Kedisiplinan

5. Prestasi kerja

\section{Pengertian Budaya Organisasi}

Menurut Robbins dan Judge (2008), budaya organisasi adalah sistem yang dianut secara bersama oleh anggota dan membedakan organisasi tersebut dengan organisasi lainnya. Stoner (1995) dalam Riani (2011:6) mendefinisikan budaya organisasi sebagai suatu cognitive framework yang meliputi sikap, nilai-nilai, norma perilaku dan harapan-harapan yang disumbangkan oleh anggota organsasi. Menurut Sutrisno (2011:2), budaya organisasi merupakan sistem berisi nilai, keyakinan, asumsi, atau norma yang berlaku dan diikuti oleh anggota organisasi sebagai standar perilaku dan solusi permasalahan organisasinya.

\section{Fungsi Budaya Organisasi}

Robbins (2006) menjelaskan bahwa budaya memiliki beberapa fungsi, yaitu sebagai berikut. 
a. Menetapkan tapal batas, yaitu membedakan satu organisasi dengan organisasi lainnya secara jelas.

b. Memberikan identitas ke anggotanya.

c. Memudahkan penumbuhan komitmen atas kepentingan organisasi.

d. Meningkatkan kemantapan atas sistem sosial, yakni sebagai perekat sosial yang menyatukan organisasi dengan standar nilai dan perilaku.

e. membentuk sikap serta perilaku anggotanya.

\section{Indikator Budaya Organisasi}

Menurut Robbins dan judge (2008:64), budaya organisasi memiliki indikator berikut ini.

a. Inovasi dan pengambilan resiko, yaitu seberapa besar organisasi mendorong anggotanya untuk berinovasi dan mengambil resiko.

b. Perhatian pada detail, yaitu seberapa besar organisasi dan anggotanya menuntut ketelitian, analisis dan perhatian terperinci.

c. Orientasi hasil, yaitu seberapa besar organisasi menekankan pencapaian sasarannya daripada cara pencapaiannya.

d. Orientasi manusia, yaitu seberapa jauh organisasi mempertimbangkan anggotanya dalam pengambilan keputusan.

e. Orientasi tim, yaitu seberapa besar organisasi menekankan pada kerja tim dalam penyelesaian tugas.

f. Agresivitas, yaitu seberapa besar organisasi mendorong karyawan untuk bersaing daripada bekerjasama, dalam upaya menciptakan beragam hasil pekerjaan.

g. Stabilitas, yaitu seberapa besar organisasi menekankan pemeliharaan status dalam pengambilan keputusan serta tindakan.

\section{Pengertian Kinerja}

Menurut Wibowo (2010:7), kinerja berfokus pada apa yang diperlukan untuk keberhasilan organisasi, manajer dan pegawai. Torang (2012:118) mendefinisikan kinerja sebagai kuantitas atau kualitas hasil kerja individu dan/atau kelompok di organisasi dalam menjalankan tugas dan fungsinya dengan mengacu ke norma, SOP, kriteria dan indikator dalam organisasi. Sementara itu, Soelaiman (2007:279) menjelaskan bahwa kinerja merupakan sesuatu yang dikerjakan/dihasilkan dalam bentuk produk maupun jasa oleh 
seseorang atau sekelompok orang melalui kemampuan, pengetahuan, kecakapan, dan pengalamannya.

\section{Aspek-Aspek Penilaian Kinerja}

Hasibuan (2006) mengemukakan bahwa kinerja dapat dinilai melaui aspek berikut ini.

1. Kesetiaan, yaitu kesetiaaan terhadap pekerjaan, jabatan dan organisasinya yang ditunjukkan oleh kesediaannya untuk menjaga dan membela organisasi.

2. Prestasi kerja, yaitu hasil kerja baik kualitas maupun kuantitas yang dihasilkan karyawan berdasarkan uraian jabatannya.

3. Kejujuran, yaitu kejujuran dalam menjalankan tugasnya untuk memenuhi janji.

4. Kedisiplinan, yaitu ketaatan terhadap peraturan dan bekerja sesuai instruksi.

5. Kreativitas, yaitu kemampuan berkreasi untuk menyelesaikan pekerjaannya dengan lebih berdaya guna dan berhasil guna.

6. Kerjasama, yaitu kesediaan karyawan untuk berpartisipasi dan bekerja dengan karyawan lain secara vertikal dan horizontal

7. Kepemimpinan, yaitu kemampuan untuk memimpin dan memberi pengaruh melalui pribadinya yang kuat, berwibawa, dihormati, dan memotivasi orang lain untuk bekerja dengan efektif.

8. Kepribadian, yaitu perilaku yang memperlihatkan sikap yang baik, serta berpenampilan simpatik dan wajar.

9. Prakarsa, yaitu kemampuan berpikir secara orisinal berdasarkan inisiatif dalam membuat keputusan.

10. Kecakapan, yaitu kecakapan dalam menyatukan dan menyelaraskan beragam elemen di dalam manajemen dan penyusunan kebijakan.

11. Tanggung jawab, yaitu kesedian untuk mempertanggung jawabkan hasil pekerjaan, sarana dan prasarana yang dipakai serta perilaku kerja.

Sementara itu, Umar (1997:266) mengemukakan bahwa aspek-aspek kinerja terdiri dari: (1) mutu pekerjaan, (2) kejujuran karyawan, (3) inisiatif, (4) kehadiran, (5) sikap, (6) kerja sama, (7) keandalan, (8) pengetahuan tentang pekerjaan, (9) tanggung jawab, dan (10) pemanfaatan waktu kerja. 


\section{Keterkaitan antara Motivasi Intrinsik dan Kinerja Pegawai}

Herzberg (1966) menyatakan bahwa pelaksanaan pekerjaan oleh seseorang dipengaruhi oleh dua faktor, yaitu faktor pemeliharaan atau faktor kesehatan (hygiene factor) dan faktor pemuas atau faktor motivasi (motivation factor). Faktor kesehatan seringkali disebut sebagai faktor motivasi ekstrinsik, sedangkan faktor pemuas seringkali disebut sebagai faktor motivasi intrinsik. Pegawai yang terdorong secara intrinsik akan menyenangi pekerjaannya dan berusaha untuk senantiasa bekerja dengan baik, sehingga senantiasa mampu mempertahankan atau bahkan meningkatkan kinerjanya. Hal ini sejalan dengan hasil penelitian Prahiawan dan Simbolon (2014) serta Waruwu (2017) yang membuktikan bahwa motivasi intrinsik berpengaruh positif dan signifikan terhadap kinerja karyawan.

$\mathrm{H}_{1}$ : Motivasi intrinsik berpengaruh positif dan signifikan terhadap kinerja pegawai Biro Kepegawaian di BKN Jakarta.

\section{Keterkaitan antara Kepuasan Kerja dan Kinerja Pegawai}

Menurut Handoko (2012:193), kepuasan kerja merupakan keadaan emosional karyawan yang menyenangkan dan/atau tidak menyenangkan dalam memandang pekerjaannya. Hasibuan (2006) mengemukakan bahwa pegawai yang memiliki kepuasan kerja akan menyenangi dan mencintai pekerjaannya, sehingga akan menunjukkan moral dan disiplin kerja yang baik terhadap pekerjaannya tersebut. Pada akhirnya, pegawai tersebut akan mampu meningkatkan prestasi dan kinerjanya. Hasil penelitian Rosita dan Yuniati (2016) serta Saputra, dkk. (2016) juga berhasil membuktikan bahwa kepuasan kerja memiliki pengaruh yang positif dan signifikan terhadap kinerja pegawai.

$\mathrm{H}_{2}$ : Kepuasan kerja berpengaruh positif dan signifikan terhadap kinerja pegawai Biro Kepegawaian di BKN Jakarta.

\section{Keterkaitan antara Budaya Organisasi dan Kinerja Pegawai}

Menurut Robbins (2006), budaya suatu organisasi dapat membentuk sikap dan perilaku para pegawai yang bekerja di organisasi itu. Penerapan budaya organisasi yang baik di dalam suatu instansi/perusahaan akan membentuk sikap dan perilaku yang baik di dalam diri pegawainya yang akan membantu pegawai tersebut untuk melaksanakan pekerjaannya dengan baik. Akibatnya, pegawai tersebut akan mampu menghasilkan kinerja yang baik. Hasil penelitian Armiaty dan Ariffin (2014) serta Warni (2014) juga menunjukkan bahwa budaya organisasi berpengaruh positif dan signifikan terhadap kinerja karyawan. 
$\mathrm{H}_{3}$ : Budaya organisasi berpengaruh positif dan signifikan terhadap kinerja pegawai Biro Kepegawaian di BKN Jakarta.

\section{Kerangka Analisis}

Kerangka analisis penelitian ini disajikan pada gambar berikut.

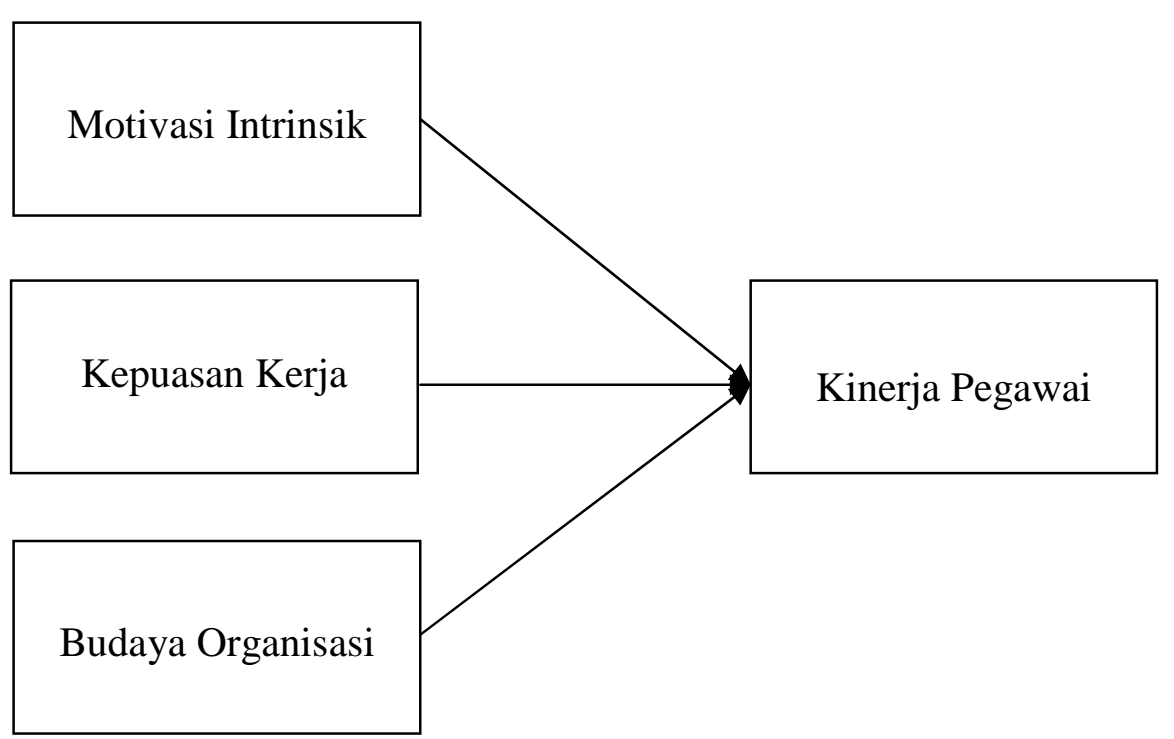

Gambar 1. Kerangka Analisis

\section{METODE PENELITIAN}

\section{Jenis dan Sumber Data}

Data penelitian ini merupakan data cross-section dan data primer yang diperoleh dari hasil penyebaran kuesioner kepada responden.

\section{Populasi dan Sampel}

Populasi penelitian ini adalah seluruh pegawai Biro Kepegawaian di Badan Kepegawaian Negara (BKN) Jakarta yang terdiri dari 172 karyawan. Pengambilan sampel dilakukan dengan teknik probability sampling, khususnya simple random sampling. Dengan rumus Slovin, jumlah sampel penelitian ini terdiri dari 120 responden.

\section{Definisi Operasional Variabel}

Definisi operasional dari variabel penelitian disajikan pada tabel berikut. 
Tabel 1. Definisi Operasional Variabel

\begin{tabular}{|c|c|c|}
\hline Variabel & Definisi Operasional & Indikator \\
\hline $\begin{array}{l}\text { Motivasi } \\
\text { Intrinsik }\end{array}$ & $\begin{array}{l}\text { Dorongan dari dalam diri } \\
\text { pegawai } \\
\text { melaksanakan pekerjaannya } \\
\text { dengan baik. }\end{array}$ & $\begin{array}{l}\text { - Prestasi } \\
\text { - Penghargaan } \\
\text { - Tanggung jawab } \\
\text { - Pengembangan diri } \\
\text { Sumber: Robbins (2006) }\end{array}$ \\
\hline Kepuasan Kerja & $\begin{array}{l}\text { Tingkat kesenangan yang } \\
\text { dirasakan oleh pegawai } \\
\text { terhadap pekerjaannya. }\end{array}$ & $\begin{array}{l}\text { - Menyenangi pekerjaannya } \\
\text { - Mencintai Pekerjaannya } \\
\text { - Kedisiplinan } \\
\text { - Prestasi kerja } \\
\text { Sumber: Hasibuan (2006) }\end{array}$ \\
\hline $\begin{array}{c}\text { Budaya } \\
\text { Organisasi }\end{array}$ & $\begin{array}{l}\text { Nilai dan sikap yang } \\
\text { diterima dan diberlakukan } \\
\text { di dalam instansi/organisasi. }\end{array}$ & $\begin{array}{l}\text { - Inovasi dan pengambilan resiko } \\
\text { - Perhatian pada detail } \\
\text { - Orientasi hasil } \\
\text { - Orientasi manusia } \\
\text { Sumber: Robbins dan judge (2008:64) }\end{array}$ \\
\hline Kinerja Pegawai & $\begin{array}{l}\text { Hasil dari } \\
\text { pegawai. }\end{array}$ & $\begin{array}{l}\text { - Mutu } \\
\text { - Loyalitas } \\
\text { - Kerja sama } \\
\text { - Tanggung Jawab } \\
\text { Sumber: Umar } \quad(1997: 266) \text { dan } \\
\quad \text { Hasibuan }(2006)\end{array}$ \\
\hline
\end{tabular}

\section{Metode Analisis}

Penelitian ini menggunakan regresi linear berganda untuk menganalisis pengaruh motivasi intrinsik, kepuasan kerja dan budaya organisasi terhadap kinerja pegawai Biro Kepegawaian di BKN Jakarta.

\section{HASIL DAN PEMBAHASAN}

\section{Hasil Uji Instrumen}

Hasil uji validitas menunjukkan bahwa setiap pernyataan kuesioner memiliki $\mathrm{r}_{\text {hitung }}>$ $\mathrm{r}_{\text {tabel}}$, sehingga bersifat valid. Sementara itu, hasil uji reliabilitas menunjukkan bahwa semua variabel memiliki Cronbach Alpha > 0,6, sehingga bersifat reliabel. Berdasarkan hasil kedua uji instrumen tersebut, instrumen penelitian ini telah memenuhi syarat-syarat instrumen penelitian. 


\section{Hasil Uji Asumsi Klasik}

Hasil uji normalitas menunjukkan bahwa data penelitian terdistribusi normal karena Asympthotic Significance (2-tailed) yang dimilikinya > 0,05. Hasil uji multikolinearitas menunjukkan bahwa tidak terjadi multikolinearitas karena setiap variabel independen memiliki tolerance $>0,1$ dan VIF $<10$. Hasil uji heteroskedastisitas menunjukkan bahwa tidak terjadi heteroskedastisitas karena korelasi antara setiap variabel independen dan unstandardized residual memiliki signifikansi $>0,05$. Sementara itu, hasil uji autokorelasi menunjukkan bahwa tidak terjadi autokorelasi karena memenuhi kriteria dU < DW < 4-dU. Berdasarkan hasil keempat uji asumsi klasik tersebut, data dan model penelitian ini telah memenuhi syarat-syarat asumsi klasik.

\section{Hasil Uji Regresi Linear Berganda}

Hasil uji regresi linier berganda disajikan dalam persamaan berikut.

$$
\mathrm{Y}=6,894+0,307 \mathrm{MI}+0,205 \mathrm{KK}+0,284 \mathrm{BO}
$$

Keterangan:

$$
\begin{array}{ll}
\mathrm{Y} & =\text { Kinerja pegawai } \\
\mathrm{MI} & =\text { Motivasi intrinsik } \\
\mathrm{KK} & =\text { Kepuasan kerja } \\
\mathrm{BO} & =\text { Budaya organisasi }
\end{array}
$$

\section{Hasil Uji F}

Hasil uji $\mathrm{F}$ menunjukkan bahwa model regresi ini bersifat layak karena memiliki $F_{\text {hitung }}$ yang positif dan $>F_{\text {tabel }}$. Hal tersebut juga menunjukkan bahwa motivasi intrinsik, kepuasan kerja dan budaya organisasi secara simultan berpengaruh positif dan signifikan terhadap kinerja karyawan.

\section{Hasil Uji Koefisien Determinasi}

Berdasarkan pengujian, besarnya koefisien determinasi dari model ini adalah 0,488 , sehingga motivasi intrinsik, kepuasan kerja dan budaya organisasi memberikan kontribusi sebesar 48,8\% dalam mempengaruhi kinerja karyawan, sedangkan 51,2\% sisanya dipengaruhi oleh variabel lainnya yang tidak dianalisis.

\section{Hasil Uji Hipotesis}

Hasil uji hipotesis menunjukkan bahwa setiap variabel bebas memiliki nilai t yang positif dengan signifikansi $<0,05$, sehingga motivasi intrinsik, kepuasan kerja dan budaya 
organisasi secara parsial berpengaruh positif dan signifikan terhadap kinerja pegawai Biro Kepegawaian di BKN Jakarta.

\section{Pembahasan}

\section{Pengaruh Motivasi Intrinsik terhadap Kinerja Pegawai}

Penelitian ini menunjukkan bahwa motivasi intrinsik berpengaruh positif dan signifikan terhadap kinerja pegawai Biro Kepegawaian di BKN Jakarta. Artinya, semakin tinggi motivasi intrinsik seorang pegawai, maka semakin tinggi kinerja pegawai tersebut. Sebaliknya, semakin rendah motivasi intrinsik seorang pegawai, maka semakin rendah kinerja pegawai tersebut. Hal ini sejalan dengan hasil penelitian Prahiawan dan Simbolon (2014) serta Waruwu (2017).

Menurut Luthans (2011), motivasi intrinsik akan mendorong pegawai untuk berprestasi. Artinya, motivasi intrinsik akan mendorong pegawai untuk menjalankan tugasnya dengan baik, sehingga pegawai tersebut dapat mencapai kinerja tinggi yang diakui sebagai prestasi kerja oleh instansi tempatnya bekerja. Pegawai yang terdorong secara intrinsik akan menyenangi pekerjaannya dan berusaha untuk senantiasa melaksanakan pekerjaannya dengan baik, sehingga senantiasa mampu mempertahankan atau bahkan meningkatkan kinerjanya. Nopitasari dan Krisnandi (2018) juga menjelaskan bahwa semakin kuat motivasi intrinsik seorang karyawan, maka semakin kuat pula keinginan karyawan tersebut untuk melaksanakan pekerjaannya dengan baik, sehingga semakin terdorong perilakunya untuk diarahkan menuju standar kinerja dan tujuan perusahaan.

\section{Pengaruh Kepuasan Kerja terhadap Kinerja Pegawai}

Penelitian ini menunjukkan bahwa kepuasan kerja berpengaruh positif dan signifikan terhadap kinerja pegawai Biro Kepegawaian di BKN Jakarta. Artinya, semakin tinggi tingkat kepuasan kerja seorang pegawai, maka semakin baik kinerja dari pegawai tersebut. Sebaliknya, semakin rendah tingkat kepuasan kerja seorang pegawai, maka semakin rendah kinerja dari pegawai tersebut. Hasil penelitian ini sejalan dengan hasil penelitian Rosita dan Yuniati (2016) serta Saputra, dkk. (2016).

Menurut Indrawan dan Dewi (2014), karyawan yang memiliki kepuasan kerja yang tinggi cenderung akan setia kepada instansi tempatnya bekerja serta termotivasi dan merasa senang dalam bekerja, sehingga dapat membantu perusahaan untuk mencapai tujuannya. Sebaliknya, karyawan yang tidak puas cenderung akan menghindari tugas dan tanggung jawabnya, sehingga dapat mengganggu proses pencapaian tujuan perusahaan. Hasibuan 
(2006) mengemukakan bahwa pegawai yang memiliki kepuasan kerja akan menyenangi dan mencintai pekerjaannya, sehingga pegawai tersebut akan menunjukkan moral dan disiplin kerja yang baik terhadap pekerjaannya tersebut. Pada akhirnya, pegawai tersebut akan mampu meningkatkan prestasi dan kinerjanya.

\section{Pengaruh Budaya Organisasi Terhadap Kinerja Pegawai}

Penelitian ini menunjukkan bahwa budaya organisasi berpengaruh positif dan signifikan terhadap kinerja pegawai Biro Kepegawaian di BKN Jakarta. Artinya, semakin baik budaya organisasi dalam suatu instansi/perusahaan, maka semakin baik kinerja pegawai dari instansi/perusahaan tersebut. Sebaliknya, semakin buruk budaya organisasi suatu instansi/perusahaan, maka semakin buruk kinerja pegawai dari instansi/perusahaan tersebut. Hasil penelitian ini sejalan dengan hasil penelitian Armiaty dan Ariffin (2014) serta Warni (2014).

Robbins (2006) mengemukakan bahwa budaya suatu organisasi dapat membentuk sikap dan perilaku pegawai yang bekerja di organisasi tersebut. Penerapan budaya organisasi yang baik di suatu instansi/perusahaan akan membentuk sikap dan perilaku yang baik di dalam diri pegawainya yang akan membantu pegawai tersebut untuk dapat melaksanakan pekerjaannya dengan baik. Akibatnya, pegawai tersebut akan mampu mencapai kinerja yang tinggi.

Berdasarkan hasil penelitian Wardani, dkk. (2016), penerapan budaya organisasi yang berasaskan integritas dan keakraban akan memberikan pengaruh yang positif dan signifikan terhadap kinerja pegawai. Kotter dan Haskett (1992) dalam Tika (2012) mengemukakan bahwa di masa depan, budaya organisasi mungkin akan menjadi suatu faktor yang lebih penting lagi dalam menentukan keberhasilan dan kegagalan suatu instansi/perusahaan.

\section{KESIMPULAN DAN SARAN}

\section{Kesimpulan}

Berdasarkan hasil penelitian, dapat disimpulkan bahwa motivasi intrinsik, kepuasan kerja dan budaya organisasi secara parsial berpengaruh positif dan signifikan terhadap kinerja pegawai Biro Kepegawaian di Badan Kepegawaian Negara (BKN) Jakarta

\section{Saran}

Berdasarkan hasil penelitian, berikut ini merupakan saran yang dapat dipertimbangkan oleh instansi. 
1. Instansi diharapkan dapat memberikan penghargaan dan pengakuan kepada pegawai berprestasi, memberikan tanggung jawab sesuai dengan kompetensi dan passion pegawainya, serta memberikan pegawainya kesempatan untuk mengembangkan diri dan potensinya, salah satunya dengan membuat sistem promosi dan jenjang karir yang jelas. Hal tersebut perlu dilakukan untuk merangsang peningkatan motivasi intrinsik pegawai.

2. Instansi diharapkan dapat senantiasa mengevaluasi kepuasan kerja pegawainya dan terus melakukan upaya yang dapat meningkatkan kepuasan kerja pegawainya.

3. Instansi diharapkan dapat membangun dan mengembangkan budaya organisasi yang positif, yaitu budaya organisasi yang tidak hanya berorientasi pada hasil, tetapi juga berorientasi pada manusia, upaya penciptaan inovasi dan pengambilan risiko, serta totalitas pada pekerjaan hingga detail terkecilnya.

\section{DAFTAR PUSTAKA}

Armiaty, R. dan Z. Ariffin. 2014. Pengaruh Budaya Organisasi dan Motivasi terhadap Kinerja Pegawai Frontliner: Studi pada Cabang Bank Kalsel yang Berada di Wilayah Banjarmasin. Jurnal Wawasan Manajemen. 2(2): 213-236.

Badan Kepegawaian Negara. 2017. http://www.bkn.go.id. 13 April 2017. (21:32).

Bangun, W. 2012. Manajemen Sumber Daya Manusia. Erlangga. Jakarta.

Danarjati, D.P., A. Murtiadi dan A.R. Ekawati. 2013. Pengantar Psikologi Umum. Graha Ilmu. Yogyakarta.

Gunarsa, S.D. 2008. Motivasi Intrinsik. Pustaka Insan Madani. Jakarta. 2008. Psikologi Perawatan. Gunung Mulia. Jakarta.

Handoko, T.H. 2012. Manajemen Personalia dan Sumber Daya Manusia. BPFE. Yogyakarta.

Hariandja, M.T.E. 2005. Manajemen Sumber Daya Manusia. Grasindo. Jakarta.

Hasibuan, M.S.P. 2006. Manajemen Sumber Daya Manusia. Bumi Aksara. Jakarta.

Aksara. Jakarta.

2006. Organisasi dan Motivasi: Dasar Peningkatan Produktivitas. Bumi .2006. Manajemen: Dasar, Pengertian dan Masalah. Bumi Aksara. Jakarta.

Herzberg, F. 1966. Work and the Nature of Man. World Publishing Company. Cleveland. 
Indrawan, D.C. dan A.A.S.K. Dewi. 2014. Pengaruh Kompensasi, Kepemimpinan dan Lingkungan Kerja Fisik terhadap Kepuasan Kerja Karyawan PT Cargo Asas International, Denpasar. E-Jurnal Manajemen Universitas Udayana. 3(6): 1767-1779.

Kotter, J.P. dan J.L. Heskett. 1992 Corporate Culture and Performance. Free Press. New York.

Luthans, F. 2011. Organizational Behavior. McGraw-Hill. New York.

Nopitasari, E. dan H. Krisnandi. 2018. Pengaruh Gaya Kepemimpinan Demokratis, Motivasi Intrinsik dan Disiplin Kerja terhadap Kinerja Karyawan PT Pangansari Utama Food Industry. Jurnal Ilmiah Ilmu Manajemen Oikonomia. 14(1): 15-30.

Prahiawan, W. dan N. Simbolon. 2014. Pengaruh Motivasi Intrinsik dan Lingkungan Kerja terhadap Kinerja Karyawan pada PT Intimas Lestari Nusantara. Jurnal Ekonomi. 5(1): $35-41$.

Riani, A.L. 2011. Budaya Organisasi. Graha Ilmu. Yogyakarta.

Rivai, V. dan E.J. Sagala. 2009. Manajemen Sumber Daya Manusia untuk Perusahaan. Raja Grafindo Persada. Jakarta.

Robbins, S.P. 2002. Organizational Behavior. Tenth Edition. Prentice Hall. New Jersey. Terjemahan B. Molan. 2006. Perilaku Organisasi. Edisi 10. Indeks. Jakarta.

Robbins, S.P. dan T.A. Judge. 2006. Organizational Behavior. $12^{\text {th }}$ Ed. Prentice Hall. New Jersey. Terjemahan D. Angelica, R. Cahyani dan A. Rosyid. 2008. Perilaku Organisasi. Edisi 12. Salemba Empat. Jakarta.

Rosita, T. dan T. Yuniati. 2016. Pengaruh Kepuasan Kerja terhadap Kinerja Karyawan dengan Komitmen Organisasional sebagai Variabel Intervening. Jurnal Ilmu dan Riset Manajemen. 5(1): 1-20.

Saputra, A.T., I.W. Bagia dan N.N. Yuliantini. 2016. Pengaruh Kepuasan Kerja dan Loyalitas Karyawan terhadap Kinerja Karyawan. E-Journal Bisma Universitas Pendidikan Ganesha. 4: (1-8).

Sardiman, A.M. 2007. Interaksi dan Motivasi Belajar Mengajar. Raja Grafindo Persada. Jakarta.

Soelaiman. 2007. Manajemen Kinerja: Langkah Efektif untuk Membangun, Mengendalikan dan Evaluasi Kerja. Intermedia Personalia Utama. Jakarta.

Sutrisno, E. 2011. Manajemen Sumber Daya Manusia. Kencana. Jakarta.

Taufik, M. 2007. Prinsip-Prinsip Promosi Kesehatan Dalam Bidang Keperawatan. Infomedika. Jakarta.

Tika, M.P. 2012. Budaya Organisasi dan Peningkatan Kinerja Karyawan. Bumi Aksara. Jakarta. 
Torang, S. 2012. Metode Riset Struktur dan Perilaku Organisasi. Alfabeta. Bandung.

Umar, H. 1997. Riset Sumber Daya Manusia dalam Organisasi. Gramedia Pustaka Utama. Jakarta.

Wardani, R.K., M.D. Mukzam dan Y.Mayowan. 2016. Pengaruh Budaya Organisasi terhadap Kinerja Karyawan: Studi pada Karyawan PT Karya Indah Buana Surabaya. Jurnal Administrais Bisnis. 31(1): 58-65.

Warni, E.D. 2014. Pengaruh Gaya Kepemimpinan dan Budaya Organisasi terhadap Kinerja Karyawan pada Sekretariat Daerah Kabupaten Temanggung. Jurnal Riset Manajemen Provesisa. 1(1): 64-77.

Waruwu, F. 2017. Analisis tentang Pengaruh Motivasi dan Motivasi Ekstrinsik terhadap Kinerja Karyawan: Studi Kasus di Rumah Sakit Rajawali dan STIKES Rajawali Bandung. Jurnal Manajemen Maranatha. 16(2): 203-212.

Wibowo. 2010. Manajemen Kinerja. Edisi Ketiga. Raja Grafindo Prasada. Jakarta. 